camera having a U.V. $15^{\circ}$ prism; the scale of the latter is such that the distance on the plate from $\mathrm{H} \beta$ to $\mathrm{H} \theta$ is $3 \mathrm{~mm}$. The outstanding features of the spectra are broad bright hydrogen lines, and a very strong bright band which Prof. Frost designates $\lambda$ 4640. On the Bruce spectrogram (scale, I mm. $=26 \cdot 0$ A.U.) dark shadings and bright maxima are suspected within these bright lines, and dark lines are seen on the more refrangible edges, especially in the cases of $\mathrm{H} \beta$ and $\mathrm{H} \gamma$. The displacements of the lines, if interpreted by line-of-sight motions, would indicate velocities varying from -1300 to $+760 \mathrm{~km}$. per second. Spectrograms taken on May 4 and 6 indicate a strengthening of the chief nebular line at $\lambda 500$, thereby suggesting that the change to the nebular state, apparently common to all novæ, had set in.

A number of observations of position, magnitude, and colour of the nova are recorded by various observers in No. 4509 of the Astronomische Nachrichten.

The TaIl of Halley's CoMet.-As an extract from No. 3 of Ciel et Terre we have received a paper in which Prof. Eginitis summarises the discussion concerning the appearance of the tail of Halley's comet on the night of May 20, 1910. Having demonstrated that an error of observation, at Athens, is out of the question, he explains the apparent digression between his observation and some others by the suggestion that at that time the earth was situated on, or very near to, the axis of the main tail. Thus only the nucleus bounded by nebulosity would be seen, and the form observed would be one that would change rapidly as the angle under which it was seen changed. The differences are thus reduced to a question of perspective, and it is argued that this would change quickly at that critical period.

The Great Red Spot on Juprter.-Mr. Stanley Williams, writing to the Astronomische Nachrichten (No. $4507)$, confirms the abnormal change of longitude of the Red Spot, which was observed by the Rev. T. E. R. Phillips and others. In addition, he remarks upon the great change in the visibility of the spot itself which has recently taken place. For several years the spot has been indistinct and not of its earlier characteristic red colour, but lately it has been, to Mr. Williams, not only a comparatively conspicuous object, but also strongly coloured. It would seem that the spot is now free from the overlying material which has for some time masked its characteristic clearness and colour. Mr. Williams's transit times, taken on May ro and $I 7$ and June $I$ and 8 , confirm the change of longitude, and show that the length of the spot has not changed; the difference of longitude, $-7 \cdot 7^{\circ}$, between June $\mathrm{I}$ and 8 , if real, is remarkable.

Definition of the Term "Double Star."--Having for some years been desirous of establishing a definite scope for the term "double star," Prof. R. G. Aitken recently prepared a scheme for this purpose and submitted it to the chief double-star observers of the world. The majority agreed that some restriction to the use of the term is necessary, while others believe that the difficulties in establishing a rigorous system would outweigh the advantages accruing from its adoption. Prof. Aitken publishes his scheme, and the correspondence respecting it, in No. 4505 of the Astronomische Nachrichten. His definition of a double star includes any two stars which come within the following limits of distance:-

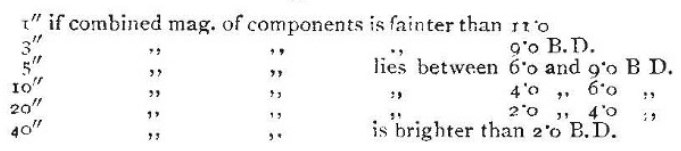

\section{JUBILEE MEETINGS OF THE INSTITUTION OF NAVAL ARCHITECTS.}

THE jubilee meeting of the Institution of Naval Architects opened on Monday evening, July 3, with a reception by the president, the Marquis of Bristol, which was attended by members and delegates from all parts of the world. H.R.H. the Duke of Connaught took the chair at the meeting on the morning of July 4 as honorary president of the congress, and the president's address was delivered at this meeting. Reference was made to the
death of the late president, Lord Cawdor, whose personality and zeal marked him out as a leader whom men would be proud to follow. The present congress had a twofold purpose- to commemorate the jubilee of the institution and to bring together from all parts of the world the great leaders in this sphere of industrial activity. The council desired to do honour to their guests from abroad, and had determined to invite the following to accept honorary membership of the institution, the highest honour in their power to confer:-H.M. the King of Norway, H.M. the King of Spain, H.M. the King of Sweden, H.I.H. Prince Henry of Prussia, H.I.H. Archduke Ferdinand, H.R.H. the Duke of Connaught, H.R.H. the Duke of Genoa, Prince Roland Bonaparte, Lord Rayleigh, Admiral Dewey, Admiral Togo, and Admiral Ijuin.

Sir William H. White gave an interesting account of the history of the Institution of Naval Architects, in which he referred to Sir Nathaniel Barnaby, the only survivor of the little group of men whose meeting on January 16 , i860, practically secured the establishment of the institution. Looking back upon work which has been done by the institution, it may be claimed that the intentions of its promoters, on the whole, have been well fulfilled; in some respects they have been surpassed. The meetings of the institution have afforded exceptional opportunities for the discussion of questions affecting the science and practice of naval architecture and marine engineering, the construction of warships and of merchant ships, the shipbuilding policy of Great Britain, the safety of life and property at sea, the introduction of new materials of construction and structural arrangements, the development of experimental methods of research, the introduction of new methods of ship calculations and design, and the discussion of new inventions of various kinds. Before the institution was founded, naval science had no home in England; its treasures lay scattered far and wide in the form of memoirs and papers contained in the Proceedings of the Royal Society or in other publications. Everything worthy of publication now naturally finds its way to the Transactions, and through them to naval architects, marine engineers, and others interested in these subjects throughout the world. Every great movement may be said to have been chronicled for fifty years.

Fifty years' architectural expression of tactical ideas formed the subject of a paper by Admiral Sir Cyprian Bridge. In the year 1860 what may be called the seventeenth-century type of man-of-war was still represented in the British Navy. The gun, as the weapon without a rival, conspicuously dominated tactics. The great change introduced in $187 \mathrm{I}$, the virtual abolition of the broadside system of arming ships, occurred at a time when the contest between the gun and armour was in full progress. Tactical considerations receded into the background. In I87 I we adopted as a weapon of war the Whitehead locomotive torpedo. It is a remarkable fact that the adoption of this weapon and the limitation of a ship's gun-armament to a small number of the heaviest guns that she could carry occurred almost simultaneously. We made no tactical provision for dealing with torpedo attacks; reliance was placed on passive defence arrangements exclusively. The French were the first to break away from the position above indicated. They had a vivid perception of the great tactical principle that concentration of the effect of weapons should be the end aimed at, and that concentration of the weapons themselves is merely the means. They armed their ships in accordance with this principle, and other nations had to follow their example. The ships launched or designed for our own navy during the last dozen years of the nineteenth century and the first two or three years of the twentieth supply monumental evidence of the reviving, but far from dominant, influence of tactics.

Fifty years' changes in British warship machinery were dealt with by Engineer-Vice-Admiral Sir Henry J. Oram. In 1860 the Navy List included a total of 499 ships, having a collective indicated horse-power of 540,000 . In I910 the number of warships was 585 , of approximately 5,000,000 indicated horse-power. The founding of the institution

No. 2 I76, vOL. 87] 
coincided with the abandonment of the paddle-wheel in favour of the screw-propeller. The warship fitted with the most powerful machinery in 1860 was the Warrior, which had engines of 5469 indicated horse-power. The introduction of surface condensers was referred to, as also tripleexpansion engines, the evaporator, and the steam turbine. The author also dealt with the troubles experienced in finding suitable boilers.

Mr. C. E. Ellis described the advances made in the manufacture of armour for ships during the last fifty years. To resist the attacks of guns of ever-increasing power, the thickness of side armour was increased from $5^{\frac{1}{2}}$ inches in the case of the Agincourt (1868) to 24 inches in the Inflexible (1881). The introduction of compound armour effected a revolution in ship protection. Its partial adoption for the turret protection of the Inflexible effected a saving of 600 tons in weight. Since then the efforts of Krupp, Captain Tresidder, and Harvey have led to great reduction in the weight of armour required. In evidence of this, a 12-inch plate, tested in 1897, was attacked by three armour-piercing projectiles of high quality. In each case the projectile was completely broken up, and no cracks appeared in the plate.

Dr. S. J. P. Thearle traced the developments in mercantile ship construction. Fifty years ago some of the ships of the mercantile marine were being built of iron, some of wood, and a small proportion were of composite construction. In 1860 the length of an average cargo steamer was less than 200 feet; now it has reached to 350 and 400 feet. Much of the development has been owing to the introduction of mild steel for iron. Finality has not yet been reached, nor is it likely to be in the near future.

It is of interest to note from the Hon. C. A. Parsons paper, on the marine steam turbine, that there are now a total of 281 war vessels, 87 mercantile vessels, and Io yachts fitted with his well-known turbines. The total horse-power of these amounts to $5,84 \mathrm{r}, 000$.

An account of the progress of naval construction in Japan was given by Rear-Admiral Motoki Kondo. At present there are four navy yards in Japan, and two large private shipbuilding yards, capable of turning out the heaviest warships complete with their machinery. Armour plates of trustworthy quality are now being produced in the Kure Navy Yard. The author understands that the process is a special one invented by Japanese engineers, and that the results are fully up to the best armour plate of the day. The progress of naval engineering in Japan was described by Engineer-Rear-Admiral Terugoro Fujii, and the development of merchant shipbuilding in the same country by Dr. S. Terano and Mr. M. Yukawa. These acknowledged the debt which Japan owes to engineers in this country for advice and help.

A paper on the design and service performance of the Transpacific liners Tenyo Maru and Chiago Maru was presented by Prof. S. Terano and Prof. Baron C. Shiba. These vessels were built in Japan; they are the largest vessels yet produced in the East, and are the first turbine steamers in Pacific waters. During the last year, and owing to the uncertainty of oil-fuel supply in Japan and China, the owners decided to burn coal. Six of the boilers were converted to use coal, and the remaining seven still burn oil. It is found that the consumption of coal is 20 to 22 tons as against 14 tons of fuel oil.

Among the many other papers presented is one by Prof. A. C. E. Rateau, on the rational application of turbines to the propulsion of warships. Owing to the low efficiency at ordinary speeds, turbine machinery reduces by one half the radius of action. This does not have much importance to Great Britain, as she has naval bases in all the seas of the world; but other nations are not in the same position as regards turbines; indeed, one of the most powerful of these is about to replace turbines by reciprocating engines for her new battleships. The author describes a combination of reciprocating engines and turbines, introduced into the French Navy in 1906, which appears to meet the case. The destroyer Voltigeur, fitted with this system, shows consumptions, at speeds below 20 knots, slightly above those obtained in destroyers fitted with reciprocating engines. Above 20 knots the consumptions remain fewer than those of all other destroyers, even with turbines only.

NO. 2 I, 6 , VOL. $8 \%]$
On Wednesday, July 5, a large company proceeded to the National Physical Laboratory for the opening of the experimental tank. An account of the opening is given in another article in this issue.

\section{THE OPENING OF THE NATIONAL EXPERI- MENTAL TANK AT THE NATIONAL PHYSICAL LABORATORY.}

THE National Experimental Tank for experiments on models of ships, recently completed at Teddington, was formally opened on Wednesday, July 5, and the great public interest taken in the work was evidenced by the number of distinguished guests who travelled to Teddington to be present at the ceremony. The chair was taken by Sir Archibald Geikie, who, as president of the Royal Society, is chairman of the general board of the laboratory, and he was supported by Lord Rayleigh, the chairman of the executive committee, with Lady Rayleigh, the Marquis of Bristol, president of the Institution of Naval Architects, and Lady Bristol; while among those occupying seats on the platform were Mr. A. F. Yarrow, Dr. Glazebrook, the director of the laboratory, and Mrs. Glazebrook, Sir Wm. and Lady White, Mr. G. S. Baker, the superintendent of the tank, and Mrs. Baker, H. E. Senor Edwards, Sir Wm. Crookes, Mr. R. W. Dana, Rear Admiral Capps, Herr Hüllmann, M. Bertin, Sir Norman Lockyer, Mr. Alex. Siemens, Sir J. W. Swan, Rear Admiral Moore, Mr. A. B. Kempe, Sir J. Rose Bradford, Sir J. Larmor, Sir Chas. Parsons, Prof. Unwin, Sir J. Wolfe Barry, Sir David Gill, and Mr. F. W. Black.

Sir Archibald Geikie, in opening the proceedings, referred to the efforts which had been made since Igor by the Institution of Naval Architects to secure the funds necessary for the construction at the National Physical Laboratory of a tank for ship-model experiments of a national character, where facilities could be provided for experimental work necessary to shipbuilders to enable them to improve and perfect the principal features in the design of their vessels. The project has now been realised owing to the generosity and enthusiasm of $\mathrm{Mr}$. A. F. Yarrow, who has provided the sum of $20,000 l$. for the construction and equipment of the tank, while the Institution of Naval Architects has secured guarantees amounting to $1340 \mathrm{l}$. per annum towards the sum of $2000 \mathrm{l}$. per annum for ten years considered necessary to ensure the successful working of the tank.

Lord Rayleigh, to whom fell the task of declaring the tank open, spoke of the pioneer work accomplished by the late Mr. William Froude, who in I871 started a tank at Torquay, and by his investigations established the fundamental principles to be followed in the application of this method of research to the science of shipbuilding. The Torquay tank was followed by the Admiralty tank at Haslar, where the work so well begun by the father is now ably continued by his son, Mr. R. E. Froude. Other tanks are now in existence in shipbuilding yards in this country, as well as on the Continent and in the United States of America. At the request of the Institution of Naval Architects, Dr. Glazebrook has visited a number of these tanks, and every assistance has been cordially rendered him, in particular by M. Bertin in Paris and by Prof. Busley and Herr Gebers in Germany, in the effort to ensure that the new national tank, for which the laboratory and the nation are indebted to Mr. Yarrow, shall be thoroughly well equipped for its work. To the realisation of the scheme the architect, Mr. Mott, and the contractors, Messrs. Dick Kerr and Co., have also largely contributed, while the superintendent of the tank, Mr. Baker, and his assistants have worked hard to ensure that the details of the equipment should be in every way satisfactory.

In his further remarks Lord Rayleigh made reference to some of the more important of the principles established by Mr. Froude, and especially to the principle of dynamical similarity, which laid down the conditions and relations governing the application of "model" methods to problems of naval architecture, as well as to similar problems in aëronautics and other subjects. In illustration of this 